\title{
Oman avun yhteisö syrjäytymistä estävänä tekijänä Tutkimus vertaistukeen perustuvista ratkaisuista ja tuloksista
}

\author{
VEIKKO VILMI
}

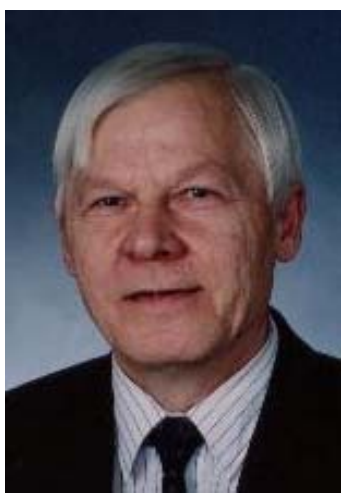

Tarkoituksenani on selvittää niitä menettelyjä, joiden avulla oman avun yhteisö voi vaikuttaa syrjäytymiseen estävästi. Esimerkkinä on kansainvälistä huomiota saavuttanut Kuopion Sirkkulanpuiston toimintayhteisö. Yhteisön toiminta muistuttaa osuuskuntatyyppistä taloudellista yhteistyötä. Artikkelin tutkimustulokset kuvaavat pyrkimyksiä edistää syrjäytymisvaarassa olevien henkilöiden hyvinvointia vertaistuen ja yhteistoiminnan avulla. Koulutuksen merkitys on oleellinen seikka syrjäytymistä estävien tavoitteiden toteuttamisessa.

\footnotetext{
Y
}

hteiskunnan kehitystä arvioitaessa (ks. Esping-Andersen 1990) yksilöt ja heidän lähipiirinsä joutunevat ottamaan yhä useammin vastuuta omasta hyvinvoinnistaan. Se luo paineita kolmannen sektorin kehittämiselle, jota on tarkasteltu eri tutkimuksissa (Nylund 2000; Jokinen \& Saaristo 2002). Yhteisöissä itseapuun perustuvat toimintaperusteet hyvinvoinnin turvaamiseksi ovat voimistuneet (ks. kuviot 1-2). Yksilöitä tukevat vuorovaikutussuhteet edistävät inmisten itsenäistä selviytymistä yhteiskunnassa (vrt. maahanmuuttajille tarkoitetut palvelut). ${ }^{1}$ Julkisen sektorin vastuu tehtävien hoitamisesta ei poistu, vaikka osavastuu onkin epävirallisella sektorilla.

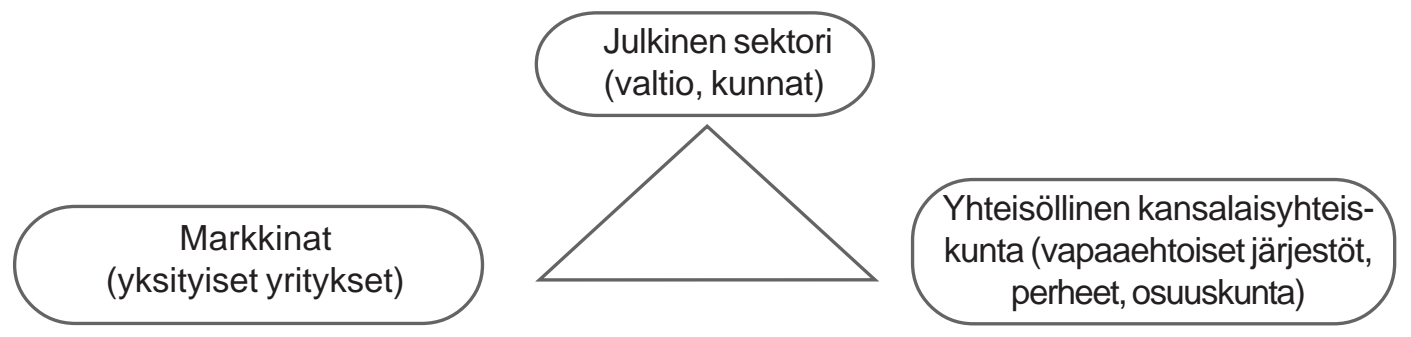


ohella. Yhteiskunnan palvelujen roolin ja hyvinvoinnin turvaamisen suunnittelu- ja toiminta-alueita olen pyrkinyt kuvaamaan mallin muodossa (Vilmi 1993, 40). Suunnittelulla ja päätöksenteolla voidaan vaikuttaa sellaisen palvelutuotannon järjestämiseen (ks. Lindeneg 1993; Johanson 1995), joka tyydyttää eri väestöryhmien tarpeita. Oma avun yhteisö on syrjäytymisvaarassa olevien erityisryhmien asuntokysymyksen osaratkaisu, jota on tarkasteltu kansainvälisestikin (esim. Murphy-Lawless 1991).

Taloudellisen laman aikana virallista järjestelmää täydentävien omaan apuun perustuvien hyvinvointipalvelujen ylläpitäminen on ollut haasteellinen tehtävä (ks. Nylund 1997; 2000), sillä julkisen vallan tuki on ollut rajallisempaa. Monen yhteisön pyrkimyksenä on ollutkin tulla toimeen omillaan ja ne ovat tukeneet toisiaan syrjäytymistä estävässä mielessä, kuten tässä katsauksessa Kuopion Sirkkulanpuiston toimintayhteisön tavoitteena on ollut vuodesta 1983 (Laurinkari 1994; Vilmi 1996; Hakaoja 2003).

\section{Sirkkulanpuiston oman avun yhteisö - tutkimuksen yleisiä määritteitä}

\section{T} arkoituksenani on selvittää niitä menettelyjä, joiden avulla oman avun yhteisö voi vaikuttaa syrjäytymiseen estävästi. ${ }^{2}$ Oman avun yhteisön esimerkkinä on kansainvälistä huomiota saavuttanut Kuopion Sirkkulanpuiston toimintayhteisö. Kyseisen yhteisön yhteistoiminta muistuttaa olemukseltaan osuuskuntatyyppistä taloudellista yhteistyötä (ks. mm. Brazda \& Kleer 1996; Miettinen 2001). Artikkelin tutkimustulokset kuvaavat syrjäytymisvaarassa olevien henkilöiden hyvinvoinnin edistämisen pyrkimyksiä, joi- ta on edesauttanut vertaistuki ja yhteistoiminta. Koulutuksen merkitys on oleellinen seikka syrjäytymistä estävien tavoitteiden toteuttamisessa.

Sosiaalisella syrjäytymisellä tarkoitetaan lyhyesti määriteltynä syrjäytymistä yhteiskunnan tuottamien palvelujen piiristä (esimerkiksi O'Cinnéide ym. 1995; Helne 2002; Jokinen \& Saaristo 2002). Syrjäytyminen merkitsee yksilötasolla jonkinasteista tarpeentyydytyksen estymistä, esimerkiksi vaikeuksia saada haluamiaan koulutuspalveluja. Tällöin huonontuvat kansalaisten mahdollisuudet integroitua yhteiskuntaan ja erityisesti työelämään (ks. Euroopan komission ...1996). Syrjäytyminen on yhteiskuntaan integroitumisen puutteen eräs mahdollinen seuraus.

Syrjäytymisvaaraa ilmenee silloin, kun joudutaan koulutuksen rekrytointivaiheessa koulutusjärjestelmän ulkopuolelle (Jahnukainen 1999, 75-84; Vilmi 1999b, 359-376). Kyseisessä tilanteessa vaikeutuvat yksilön mahdollisuudet hankkia niitä tietoja ja taitoja, joita tarvitaan yhteiskunnassa selviytymiseksi.

Koulutusura voi myönteisessä tapauksessa luoda edellytyksiä yksilön ulkoiseen ja sisäiseen elämänhallintaan (ks. Sirkkulanpuiston palvelusuunnitelma 2002, Hakaoja 2003, 12). Koulutuksella on myös keskeinen merkitys työelämään sijoittumiseen (ks. rekrytointimalli integroiduttaessa koulutusjärjestelmän kautta yhteiskuntaan / työelämään, Vilmi 2003, 13).

Oma-apuryhmät ovat kolmannen sektorin toimintaa (kuviot 1-2) perustuen vapaaehtoisuuteen, maksuttomuuteen ja osallistujien keskinäiseen vertaistukeen yhteisten ongelmien ratkaisemiseksi. Virallisen avun puute tai riittämättö-

KUVIO 2. Julkisten palvelujen mahdollisia muutossuuntia koskien esimerkiksi kolmannen sektorin palvelujen tuottamista ja rahoittamista (Vilmi 1993, 204)

MUUTOSSUUNTA1. yksityistämisvaateet

\section{Yksityinen sektori} (markkinat)
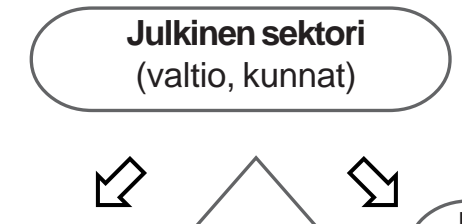

MUUTOSSUUNTA2.

omavastuistamisvaateet

Yhteisöllinen sektori

(kansalaisyhteiskunta) 
KUVIO 3. Oman avun yhteisö vertaistukineen syrjäytymistä estävänä tekijänä teoreettisten (integroitumisen negaatio on syrjäytyminen) ja operationaalisen käsitteen valossa (vrt. Vilmi 2003, 11)

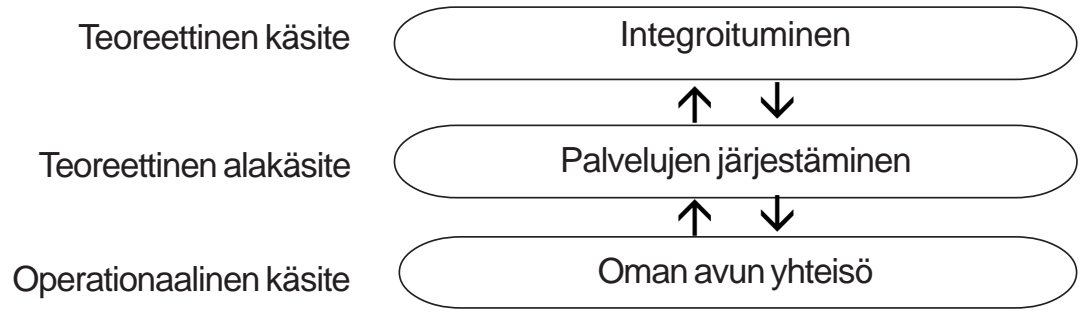

myys voivat vaikuttaa ryhmien perustamiseen. Oma-apuryhmien lisääntymistä selitetään sosiaalisten verkostojen muutosten avulla. Kyseiset ryhmät nähdään eräänä tapana korvata perinteiset yhteiskunnassa vallitsevat sosiaaliset verkostot. (Nylund 1997; 2000.)

Seuraavassa kuvaan tämän katsaustyyppisen artikkelin teoreettiset ja operationaaliset käsitteet sekä käsitteiden vaikutusyhteydet (kuvio 3). Keskeistä on pohtia hyvinvoinnin kannalta sitä, missä määrin ja kuinka kauan yhteiskunta on luonut puitteet tarkasteltavan oman avun yhteisön mahdollisuuteen järjestää palveluja ja auttaa samalla koulutusyhteiskuntaan sosiaalistumisessa (Vilmi 1999a). ${ }^{3}$ Sirkkulanpuiston toimintayhdistys on vakiinnuttanut asemansa, koska se on toiminut jo 20 vuoden ajan.

Sirkkulanpuiston toimintayhteisöä tutkittiin 1990-luvun alkupuolella seikkaperäisesti, koska kyseinen yhteisö muodosti kiinnostavan kolmannen sektorin (ks. kuviot 1-2) tutkimuksen kohteen 1990-luvun taloudellisen laman aikoihin. Tutkimuksen seurannassa olivat silloin Sirkkulanpuiston vuokra-asuntoihin joulukuun 1990 ja huhtikuun 1991 välisenä aikana muuttaneet henkilöt. Tutkimusjoukkoon kuului kymmenen asukasta, joista naisia oli yksi ja miehiä yhdeksän. Heidän ikänsä vaihtelivat 28-60 vuoden välillä, keski-iän ollessa 42 vuotta. (Laurinkari 1994, 12; vrt. myöhemmästä yhteisön seurannasta, Hakaoja 2003.)

Tutkimus toteutettiin haastattelemalla ja havainnoimalla asukkaita. Asukkaita koskevat haastattelut olivat teemahaastatteluja. Haastattelujen lisäksi tehtiin seitsemän kuukauden ajan havainnointeja tutkittavien asukkaiden keskuudessa lähes viikoittain. Havainnoinnin lisäksi tutustuttiin Sirkkulanpuiston kokouspöytäkirjoihin ja muihin vastaaviin dokumentteihin (vrt. Hakaoja 2003). Sirkkulanpuiston toimintaa seurattiin myös vuosina 1992 ja 1993. (Laurinkari 1994, 13-14.)

Tutkimuksessa pyrittiin aineiston sisäiseen validiuteen usein toistuvien kenttäkontaktien avulla sekä lisäämällä havaintojen objektiivisuutta kahden havainnoijan avulla (vrt. Hakaoja 2003). Teemahaastattelun sisältövalidiuteen pyrittiin laatimalla tarpeeksi useita kysymyksiä ja lisäkysymyksiä kultakin teema-alueelta. Tällä tavoin saavutettiin niitä merkityksiä, joita haluttiin tavoitella. Haastattelujen ulkoista validiutta tarkasteltiin vertaamalla haastattelutietoja muulla tavoin kerättyyn tietoon. (Laurinkari 1994, 14-15.)

Tutkimuksessa pyrittiin myös käsitevalidiuteen johtamalla kunkin osatutkimuksen teoreettisesta viitekehyksestä keskeiset käsitteet, joiden avulla haastatteluteemat ja havainnoinnin kohteena olevat tekijät on muodostettu (Laurinkari 1994, 15).

Sirkkulanpuiston toimintayhdistystä kuvaavassa seurannassa on myöhemminkin käytetty haastattelumenetelmää kerättäessä taloudellisena nousukautena tutkimustietoa 1990-luvun puolesta välistä eteenpäin tähän päivään saakka. Saatuja tutkimustuloksia täydennettiin yhdistyksen arkiston lehtileikkeiden, opinnäytetöiden ja kokous- ja asiakirjojen avulla (Hakaoja 2003).

\section{Vertaistuki ja hyvinvointiratkaisut}

$\mathrm{N}$ ykyaikainen yhteiskunta on koulutusyhteiskunta, jossa sosiaalinen asema määräytyy melko pitkälti koulutuksen perusteella (ks. Heikkinen ym. 1999; Jauhiainen ym. 2001). Teknistynyt yhteiskunta vaatii korkeaa ammattitaitoa, joka saavutetaan koulutuksen avulla. Tällaisessa yhteiskunnassa heikosti koulutetuilla henkilöillä on suuria vaikeuksia integroitua työelämään. Koulutuksesta syrjäytyminen tarkoittaa heikkoa kiinnittymistä yhteiskunnan koulutusjärjestelmään. Kouluyhteisössä syrjäytyminen aiheuttaa vaikeuksia päästä osalliseksi kouluyhteisön ihmissuhteista ja kulttuurista. Jahnukainen (1999, 
75-84) on pohtinut koulutuksellista syrjäytymistä ja sen ehkäisemistä peruskoulun yläasteen ja toisen asteen nivelkohdassa, muiden muassa erityisopetuksen näkökkulmsta.

Vaikeissa elämäntilanteissa lasten ja nuorten persoonallisuuden kehittymistä voivat ohjata arvot, jotka heikentävät yksilöllisen kasvun edellytyksiä. Perheen rakenne ja toimivuus sekä siinä vallitsevat sisäiset suhteet ovat tärkeitä hyvinvointiin vaikuttavia seikkoja. Lasten ja nuorten toimintaympäristöä perheyhteisyystekijöiden ohella ei voida sivuuttaa arvioitaessa Sirkkulanpuiston asukkaiden aikaisempia kehitysvaiheita ja heidän sosialisaatioprosessiaan.

Sirkkulanpuiston asukkaiden elämä aikaisemmin lapsuudessa ja nuoruudessa on ollut ongelmallista (ks. Laurinkari 1994; Hakaoja 2003). Heidän kasvuympäristöään ovat varjostaneet asumisongelmat, työttömyys, avioerot, pysyvien ihmissuhteiden puute ja alkoholiongelmat. Nämä seikat ovat heijastuneet myös kouluelämään.

Syrjäytymisvaarassa olevien erityisryhmien koulutusta on hyödyllistä pohtia kuntouttavien koulutusratkaisujen näkökulmasta. Hyvinvoinnin lähtökohtana on tyydytetty aineellinen perustarve eli ensi sijassa asumisjärjestelyt, sillä ilman asuntoa on erittäin vaikea tulla toimeen. Asuminen myötävaikuttaa muiden tarpeiden tyydyttämistä, esimerkiksi saada koulutusta yhteiskunnassa selviytymistä varten (vrt. tavoitteet tarveteorioiden kannalta, Alderfer 1969, 142-175; Allardt 1976, 37-39).

Perheen toimintaa ovat ohjaamassa arvot. Ne ovat ympäristöstä opittuja, yleisiä ja pysyviä valintataipumuksia sekä päämäärän asetteluja (esim. Allardt 1976). Arvojen sisäistäminen on eräiltä osin jäänyt joiltakin henkilöiltä vajaiksi. Siitä on aiheutunut heille vaikeuksia viranomaisten taholta (ks. Hyväri 2001), mikä on edesauttanut kierrekehityksen syvenemistä.

Vaikka hyvinvoinnin kasvuedellytykset yksilötasolla ovat näyttäneet huonohkoja ennusteita, joillakin henkilöillä on ollut voimavaroja elämäntavan muutokseen ja Sirkkulanpuiston oman avun yhteisön toiminnan käynnistämiseen 1980luvun puolesta välistä lähtien (Laurinkari 1994; Vilmi 1996; Hakaoja 2003).

Seuraavassa kuvaankin eräänä esimerkkinä yksilön muutosta ja hänen pyrkimystään selviytyä yhteiskunnassa ja auttaa myös muita vertaistukea tarvitsevia henkilöitä (vrt. Hyväri 2001):

"Minulla oli henkistä voimaa enemmän kuin riittämiin. Jonnekin piti energiaa purkaa. Aloitin taistelun asunnottomien puolesta kotikaupungissani. Asuin välillä teltassa leirintäalueella. Sieltä käsin tein mielenilmaisuiskuja kaupunkiin. Hankin luvat poliisilta ym. ja leiriydyin useaan otteeseen päivien jaksoja kaupungintalon eteen torille. Lopulta sain tekniseltä lautakunnalta vuokra-asunnon."

"Tämä minun kautta tapahtunut taistelu asuntopulan poistamiseksi rohkaisi ilmeisesti muitakin. Esimerkiksi opiskelijat pystyttivät myöhemmin torille ison mielenosoitusteltan opiskelija-asuntojen puolesta."

"Taistelu on jatkunut asuntoasian ohella monessa muussa asiassa. Päämääränä on ollut, että siellä, missä heikommat apua tarvitsevat, siellä olen minäkin. Keinojani on ollut paljon. Ne ovat suoraviivaisia, rehellisiä, byrokratian koukeroita nopeasti oikaisevia, tavoitteeltaan selkeitä, ainakin minun mielestäni. Teen työtä oman kokemukseni, oppieni ja tietojeni varassa, kansalaisena. En hyväksy sanaa yksityisenä, vaan kansalaisena. Se on yhteisvastuullisuutta."

"Samalla autan kavereita byrokratian ja oikeuden viidakossa. Jokainen voittamani oikeustaistelu on minulle näyttö siitä, että ihmisen arvo ei riipu tittelistä." (Mutta-lehti 3/ 1985; ks. myös Laurinkari 1994; Hakaoja 2003.)

\section{Muita esimerkkejä vertaistuen kokemuksista}

\section{$\mathrm{V}$}

ertaistuen vaikutusta yksilötason hyvinvoinnin myönteiseen kehittymiseen ja syrjäytymisen estämiseen on myöhemminkin tutkittu ja raportoitu 2000-luvullakin. Yksilöllisten tavoitteiden toteutumisessa on ollut merkittävää saada koulutusta, mikä on helpottanut koulutusyhteiskuntaan sosiaalistumisessa (vrt. Hakaoja 2003).

Hyväri (2001) on analysoinut haastattelututkimuksessaan pitkien vankila-, päihde- ja mielenterveyskierteistä selviytyneiden henkilöiden tarinoita. Kun omat kokemukset on ensin pyritty työstämään henkilökohtaisesti, sen jälkeen on ollut helpompi astua avoimesti yhteisölliseen vuorovaikutukseen muiden vertaisryhmään kuuluvien kanssa. Tässä on tarvittu eri tavoin tapahtuvaa tukemista (vrt. Hirvonen \& Martin 1991; Hartikainen \& Immonen 1993; Japola \& Kuikka 
1993; Hakaoja 2003). Henkilöiden kuntoutuminen on mahdollistanut jonkinlaisen uudenlaisen hoitokulttuurin syntymistä. Toiminnan arviointia voidaan tarkastella sosiaalipedagogisesta näkökulmasta, sillä kyse on syrjäytymisvaarassa olevien inmisten tukemisesta ja auttamisesta yksilöllisesti eri tavoin (vrt. Sirkkulanpuiston palvelusuunnitelma 2002, Hakaoja 2003, 12).

Eräs Hyvärin (2001) haastattelema henkilö ryhtyi kuntoututtuaan aktiivisesti perustamaan omaa hoitokotia oltuaan yli puoli vuotta päihteettömänä ja poissa vankilasta:

"Eihän siihen silloin kukaan uskonut. Minulla oli kuitenkin visio, johon uskoa. Minä menin kentälle, siltojen alle ja metsiin kertomaan pojille, että jos minäkin selvisin, tekin voitte selvitä."

"Kun minun luo tulee kaveri, minä en käske sitä mihinkään, vaan kerron vain omista kokemuksista. Sitten se huomaa, että minä olen ihan samanlainen kuin se ja rupeaa miettimään asioita. Kaveri valitsee itse ja kulkee rinnalla."

Toinen Hyvärin (2001) haastattelema henkilö, jolla oli takanaan pitkä alkoholismi- ja vankilakierre, pohdiskelee perustettuaan oman hoitoyksikön, mikä oikein meni hänen kohdallaan pieleen niin sanotun yhteiskunnan virallisen palvelujärjestelmän suhteen (vrt. Laurinkari 1994; Hakaoja 2003):

"Asioita hoidettiin aina viimeisen päälle kuntoon. Siihen perimmäiseen tuskaan ja katkeruuteen ei kuitenkaan puututtu. Näitä tuskaisia tunteitaanhan alkoholistit ja narkomaanit juuri yrittävät helpottaa."

Sirkkulanpuiston asukkaiden elämäntapa sai uutta sisältöä, kun varsinainen toimintayhdistys perustettiin vuonna 1983 ja tehtävien laajentuessa yhdistys rekisteröitiin vuonna 1984 (Laurinkari 1994; Hakaoja 2003). Kolmen henkilön voimin lähdettiin tukemaan toisia, joilla oli vaikeuksia elämässään (vrt. Hyväri 2001). Palveleva puhelinpäivystys oli ensimmäisiä auttavia toimintamuotoja. Vähitellen suunniteltiin ja toteutettiin myös muita uusia omaan apuun perustuvia toimintoja (vrt. Nylund 1997; 2000), jotka pitävät sisällään kolme lämpöistä ässää eli tukea tarvitsevan on saatava soppaa saippuaa ja sielunhoitoa.

Toimintapaikkana oli aluksi kerhotila pari kertaa viikossa muutaman tunnin kerrallaan. Vä- hän myöhemmin yhdistys sai kaupungilta käyttöönsä purkutalon, johon suunniteltiin kirpputori, itsepalvelukeittiö, sosiaalikahvila, vaatehuoltotilat ja tilapäisiä yöpymispaikkoja.

Sirkkulanpuistolla on nyt 12 toimipaikkaa eri puolilla Kuopiota (Hakaoja 2003), muun muassa koulutusta tarjoava Omatoimiopisto Messi vuodesta 1996 alkaen. Sen palvelut on suunnattu ensisijaisesti 16-25-vuotiaille uraansa ja tulevaisuuttaan suunnitteleville nuorille. Messissä tapahtuva työharjoittelu koostuu sellaisista tehtävistä, jotka auttavat nuorta valmistautumaan pääsykokeisiin. Samaan aikaan Messissä on 510 työharjoittelijaa ja kaksi ohjaajaa. Työvoimapiiri on tukenut taloudellisesti yhdistystä työttömille tarkoitetun omatoimisuuskoulutuksen järjestämisessä. Sen puitteissa on ollut mahdollisuus toteuttaa useita koulutustilaisuuksia koulutustarpeiden tyydyttämiseksi. Koulutustoiminta on ollut osa yhteisön yleistä toimintaa, jossa liikevaihto on ollut melko huomattavaa. Osan tarvittavasta rahoituksesta yhdistys on saanut ulko-puolisena rahoituksena ja osan yhdistyksen toiminnasta johtuvina tuloina.

\section{Hyvinvointikäytäntöjä}

Se uraavassa esitetään luettelomaisesti, miten Sirkkulanpuiston oman avun yhteisö on 2000luvulla pyrkinyt estämään syrjäytymistä. Samalla nähdään, miten laajaksi yhdistyksen toiminta on edennyt 1980-luvun puolesta välistä lähtien (Hakaoja 2003, 12):

Tavoitteena on tukea ja lisätä yksilöllisesti asukkaan toimintakykyä ja terveyttä sekä turvata hänen lakisääteiset oikeutensa. Psyykkinen ja sosiaalinen tuki, liikunta, ravitsemusneuvonta, juridinen neuvonta sekä kunnan palveluihin ohjaaminen ovat myös niitä sisältöjä, joihin kiinnitetään huomiota. Asiakasryhminä ovat päihdeongelmaiset, moniongelmaiset ja vajaakuntoiset sekä huono-osaiset. Toimipaikkoina ovat Likolahden asuinyhteisö, Puistolan asuinyhteisö, Sateenkaari-talo ja Siikalahden lämmittelysuoja.

Sirkkulanpuiston toimintayhdistyksen vuoden 2002 palvelusuunnitelma pyrki kiinnittämään huomiota asumispalvelujen ohella myös niihin menettelyihin, joilla katsottiin olevan vaikutusta työllistymiseen (Hakaoja 2003, 12):

Tavoitteena on kehittää ja ylläpitää työntekijöiden ammattitaitoa sekä työ- ja opiskelukykyä. Lakisääteinen kuntouttava työtoiminta ja vajaa- 
kuntoisten sosiaalinen työllistyminen ja työharjoittelupaikat sekä niihin liittyvä ohjaus ovat toiminnan sisältöinä. Vapautuvien vankien sosiaalityö, maahanmuuttajien kotouttamistyö ja oma-aputoiminta kuuluvat myös toimintaan. Asiakasryhminä ovat vajaakuntoiset, työmarkkinoiden ulkopuolelle jääneet ja uravalintoja tekevät nuoret. Toimipaikkoina ovat kierrätyskeskus, valmennuskeskus Messi ja Puistola.

Sirkkulanpuisto on kehittynyt 20 vuoden toimintansa aikana yhteisöksi, jonka toimintaperiaatteena ovat olleet yhdistyksen sitoutumattomuus ja puolueettomuus (Laurinkari 1994; Hakaoja 2003). Merkittäviä hankkeita ovat aikoinaan kymmenen tukiasunnon rakentamisen ohella Selvistuvan toiminnan käynnistäminen ja kierrätyskeskuksen perustaminen. Nämä ovat itsenäisiä toimintayksiköitä ja työllistävät lukuisia henkilöitä eri tavoin (ks. Hakaoja 2003). Kierrätyskeskus on tarjonnut tavarankierrätyksen ohessa omatoimisille nuorille mahdollisuuden toteuttaa itseään musiikkia harrastamalla.

\section{Nuorten hyvinvointia tukevia tekijöitä}

Tutkiessani kuopiolaisten asukkaiden tyytyväisyyttä kunnan tarjoamiin koulutuspalveluihin käyttämälläni analyysimenetelmän avulla löysin faktorin, jonka nimesin tyytyväisyydeksi kouluja nuorisoasioihin (Vilmi 2005, 61):

Tyytyväisyys koulu- ja nuorisoasioihin -faktori:

$\begin{array}{lc}\text { Muuttujat } & \text { Lataukset } \\ \text { Nuorten ammattikoulutus } & .70 \\ \text { Kouluolot } & .66 \\ \text { Kansalais- ja työväenopistot } & .62 \\ \text { Nuorison harrastustoiminta } & .58 \\ \text { Torit ja torikauppa } & .50\end{array}$

Kyseisen faktorin muuttujien informaatio kuvaa nuorten koulutusta ja harrastustoimintaa (vrt. Sirkkulanpuiston nuoria tukeva toiminta, Hakaoja 2003, 13-14). Palvelujen järjestyminen yhteiskunnassa vaikuttaa nuorten hyvinvointiin ja syrjäytymisvaaraan ennalta ehkäisevästi. Yhteiskunnan palvelutuotantoa kuvaavat hyvinvointiulottuvuudet voidaan esittää viitenä faktorina, jotka tutkimukseni (Vilmi 2005, 61) mukaan ovat tyytyväisyys kaupunkisuunnitteluun ja ympäristönhoitoon, koulu- ja nuorisoasioihin, sosiaalija terveydenhuoltoon, elinkeinotoiminnan edistämiseen ja asumisedellytyksiin. Nämä ovat niitä hyvinvointiulottuvuuksia, jotka koskettavat myös Sirkkulanpuiston toimintayhdistyksen asukkaita. Kerhotoiminta peruskoulun ala- ja yläasteella sekä koululaisten iltapäivähoito ovat myös tärkeitä lasten nuorten hyvinvoinnin kannalta.

Harrastusyhteisöt yleisesti tarjoavat henkilölle mahdollisuuden kokea yhteenkuuluvuuden tunnetta toisten kanssa ja toteuttaa samalla itseään hankkimalla tarvitsemiaan tietoja ja taitoja (Laurinkari 1994; Hakaoja 2003). Ne voivat merkittävällä tavalla täydentää kouluyhteisöjen ja koulutusjärjestelmän välittämiä kansalaisvalmiuksia sekä lievittää koulutuksesta ja kouluyhteisöstä syrjäytymisestä aiheutuneita vaikeuksia yksilön elämässä. Harrastusyhteisöstä syrjäytyminen on osattomuutta kansalaisyhteiskunnan (ks. kuviot 1-2) toimintajärjestelmistä, joissa henkilö yhdessä toisten kanssa toteuttaa ja kehittää itseään kansalaisena.

Sirkkulanpuiston toiminnan kasvaessa yhdistys on ollut yhä enemmän vuorovaikutuksessa viranomaisten kanssa (Laurinkari 1994; Hakaoja 2003). Sitä osoittaa Kuopion kaupungin viralliseen päätöksentekoon liittyvä dokumenttiaineisto, jossa on käsitelty kaupungin suhtautumista moniin yhdistyksen taholta tulleisiin kehittämishankkeisiin. Viranomaisia horjutti aluksi Sirkkulanpuiston toiminnan uskottavuus hoitaa raittiustyötä (ks. raittiustyöstä, mm. Piispa \& Kirsi 1986), koska se on yleensä mielletty virallisen organisaation kontrollin alaiseksi. Monet yhteisön jäsenet ovat kuitenkin pitäneet itseään parhaina asiantuntijoina ratkaista hyvinvointiinsa kuuluvia kysymyksiä.

Sirkkulanpuiston toiminnassa sosiaaliset auttamiskeinot ja tukitoimet ovat olleet moninaisia (ks. aikaisemmin esillä ollut Sirkkulanpuiston palvelusuunnitelma 2002, Hakaoja 2003, 12). Ne ovat tarjonneet yhteisön jäsenille olemassaolon, yhteisyyden ja kasvun mahdollisuuksia. Turvallisuutta ovat lisänneet yhdistyksen perustamat asunnot, työhön liittyvät toiminnot ja siitä saatu toimeentulo. Pyrkimyksenä on ollut myös yhteisöturvan, yhteisöön kuulumisen merkityksen arvostaminen sekä itsenäisyyden ja itsemääräämisoikeuden kasvun vahvistaminen (vrt. tavoitteet tarveteorioiden kannalta).

Alderferin $(1969,142-175)$ kehittelemässä niin sanotussa ERG (existence, relatedness, growth) -teoriassa tarpeet luokitellaan olemassaolon tarpeisiin (E), yhteisyyden tarpeisiin (R) ja kasvutarpeisiin (G). Allardt (1976, 37-39) on 
myös käyttänyt samantapaista luokittelua, johon erityyppiset tarpeet hänen mielestään sijoittuvat. Hänen luokittelunsa on elintaso (having), yhteisyyssuhteet (loving) ja itsensä toteuttaminen (being). Allardtin (1976) tarveteoriassa asuminen kuuluu having-ulottuvuudelle.

\section{Asuminen on myös oppimisprosessi}

$$
\text { L }
$$

aitoksesta kotiuttamista odottaville, päihdetai mielenterveysongelmaisille ja vähävaraisille yksinäisille henkilöille on ollut osin vaikeuksia osoittaa asuntoja (Laurinkari 1994; Hakaoja 2003). Yhteiskuntapolitiikan tavoitteena on saada heidät asumaan muiden kansalaisten keskuuteen. Pyrkimyksessä ei ole aina onnistuttu. Ratkaisuja ovat osin vaikeuttaneet asenteet. Pitkään asunnottomana olleita henkilöitä ei ole haluttu aina valita vuokra-asuntoihin. Heidän on pelätty aiheuttavan häiriötä naapureille ja leimaavan muut asuntoalueen ihmiset erityisryhmiksi. Osalla erityisryhmiin kuuluvista inmisistä on vaikeuksia asua perinteisissä vuokra-asunnoissa. Heille olisi kyettävä tarjoamaan sopivia asumisratkaisuja (ks. lähemmin vaihtoehtoisesta asuntopolitiikasta, Laurinkari \& Vilmi 1994, 36-43; ks. myös Hakaoja 2003).

Kuopion Sirkkulanpuiston asumisjärjestelyjen on havaittu olevan pitkään asunnottomille osin parempi vaihtoehto kuin perinteiset vuokra-asunnot. Kun asunnot olivat muutettaessa viimeistelemättömiä, asukkaat saattoivat omatoimisesti täydentää rakentamista (vrt. ammatillisen koulutuksen merkitys tavoitteiden toteuttamisessa, Hakaoja 2003, 12). Säännöt ja valvonta eivät olleet niin tarkkoja, että ne olisivat estäneet asukkaita suunnittelemasta asuntojaan ja ympäristöään mieleisellään tavalla. Rakentamisessa voitiin toteuttaa yksilöllisesti joustavia ja muunneltavia ratkaisuja.

Asuminen on oppimisprosessi, joka on helpompi aloittaa tuetusta asumisesta. Kun asuminen onnistuu kyseisessä asumismuodossa, siitä voi muuttaa tavanomaisiin vuokra-asuntoihin (Laurinkari 1994; Hakaoja 2003). Sirkkulanpuiston asuntoratkaisu on eräs ratkaisu syrjäytymisvaarassa olevien henkilöiden asumispulmiin.

Nykyisin maahanmuuttajien asuntokysymysten ratkaisut ovat ajankohtaisia niin sanotun kotouttamisen tavoitteiden kannalta. Miten pitkään vas-taanottokeskukset toimivat asukkaiden pysyvinä asuinympäristöinä? ${ }^{4}$

\section{Sirkkulanpuiston syrjäytymistä} estävä malli

$\mathrm{K}_{\mathrm{u}}$ uopion Sirkkulanpuiston oman avun yhteisö on 1980-luvulta alkanut ja 20 vuotta kestänyt syrjäytymistä estävä hanke, jonka tarkoituksena on yksilötason hyvinvoinnin turvaaminen (Laurinkari 1994; Hakaoja 2003). Teemana on ollut Toinen toistaan tukien kadulta kotiin. Kyseinen asuin- ja toimintayhteisö on pyrkinyt tarjoamaan asunnon ja tarvittavaa vertaistukea niille henkilöille, joilla on ollut vaikeuksia elämässään ja pudonneet yleisiltä asuntomarkkinoilta. Sirkkulanpuiston mallilla saattaa olla laajempaakin kantavuutta sosiaali- ja terveydenhuollon kamppaillessa resurssiongelmissaan (vrt. Esping-Andersen 1990).

Sirkkulanpuiston toimintayhteisön tarkoituksena on ollut monin keinoin tukea elämässä selviytymistä ja estää syrjäytymistä (ks. palvelusuunnitelma 2002, Hakaoja 2003, 12). Tavoitteena on ollut saada yksilön ulkoinen ympäristö ja sisäinen elämä tasapainoon. Sirkkulanpuiston toimintapoja on toteutettu muillakin paikkakunnilla (ks. luettelo toimintapaikoista, Hakaoja 2003, 9). Toiminnan laajentuminen on lisännyt vuorovaikutusta julkisen sektorin kanssa suunniteltaessa koulutusratkaisuja ja asuntohankkeita. Toiminta on tukenut syrjäytymisvaarassa olevien erityisryhmien yhteisöllisyyttä (vrt. Hyväri 2001). Monia henkilöitä on siirtynyt laitoshoidosta avohoitoon, mikä on lisännyt auttavien tahojen tarvetta osallistua kansalaisten hyvinvoinnin kehittämiseen resurssiensa rajoissa.

Tulevaisuudessa asumisen, työn ja toimeentulon sekä koulutuksen kokonaisuutta on syytä koordinoida nykyistä kiinteämmin. Se on yhteiskuntapolitiikan haaste, johon kuuluu yhä enenevässä määrin nyt myös kotouttamisen käsitteen alaan liittyvät yhteiskunnalliset ratkaisut.

Sirkkulanpuiston asunnot ovat siirtymäkauden ratkaisu tavallisiin vuokra-asuntoihin. Yhteisön asuinalueelta poismuuttaneille asunto on yleensä merkinnyt muutosta parempaan asumistasoon. Pysyvää asumista Sirkkulanpuistossa ei voida pitää epäonnistumisena siellä viihtymistä arvioitaessa (Hirvonen \& Martin 1991; Hartikainen \& Immonen 1993; Japola \& Kuikka 1993). Yhteisöasuminen on vastannut heidän yksilöllisiä tarpeitaan ja valitsemaansa elämäntapaa yleensä (vrt. Nylund 1997; 2000).

Asukkaat ovat saaneet oikeuden osallistua 
asuntoaan koskevaan hallintoon, järjestyksen- ja taloudenpitoon ym. pää-töksentekoon. Yhteisön kannalta myönteiseen kehitykseen on yritetty vaikuttaa sosiaalisen vertaistuen ja kontrollin avulla. Demokraattisten pelisääntöjen sisäistäminen on ollut tärkeä edistysaskel sosiaalistuttaessa koulutusyhteiskuntaan (ks. Jauhiainen ym. 2001; Vilmi 2005). Ennen kuin tähän vaiheeseen on päästy, se on edellyttänyt merkittävää elämäntavan muutosprosessia ja yleensäkin selviytymistä tukevia toimia.

Kuopion Sirkkulanpuiston oman avun yhteisön tutkimukseen perustuva seuranta 1980-luvulta 2000-luvulle osoittaa, että yhteiskunnassa olisi pyrittävä ottamaan huomioon vertaistuen merkitys ja kansalaisten erilaiset elämäntilanteet ja -tavat arvioitaessa hyvinvoinnin kehittymistä. Kiinnitettäessä huomiota kansalaisten syrjäytymisvaaroihin vaikutetaan turvallisuuden lisääntymiseen. Syrjäytymistä voidaan estää esimerkiksi erityisryhmien asumisjärjestelyjen avulla. Sosiaalistettaessa koulutusyhteiskuntaan syrjäytymistä on mietittävä myös kuntouttavien koulutusratkaisujen kautta.

\section{Lähteet}

Alderfer, C. P. (1969). An empirical test of a new theory of human needs. Organizational Behaviour and Human Performance 1969 (4), 142-175.

Allardt, E. (1976). Hyvinvoinnin ulottuvuuksia. WSOY.

Brazda, J. \& Kleer, J. (toim.1996). Genossenschaften vor neuen Herausforderungen. Festschrift für DDr. Juhani Laurinkari. Augsburg: Maro Verlag.

Esping-Andersen, G. (1990). The three worlds of welfare capitalism. Oxford: Polity Press.

Euroopan komission valkoinen kirja koulutuksesta (1996). Opettaminen ja oppiminenkohti kognitiivista yhteiskuntaa. Luxemburg: Euroopan yhteisöjen virallisten julkaisujen toimisto.

Hakaoja, M. (toim.2003). Sirkkulanpuiston toimintayhdistys 20 vuotta. Sirkkulanpuiston toimintayhdistys ry.

Hartikainen, P. \& Immonen, V. (1993). Vaihtoehtoinen asuntopolitiikka ja sosiaalinen tuki asumisessa. Esimerkkinä Kuopion kaupungin Sirkkulanpuisto. Kuopion yliopisto. So- siaalitieteiden laitos. Pro gradu -tutkielma.

Heikkinen, A., Korkeakangas, M., Kuusisto, L., Nuotio, P. \& Tiilikkala, L. (1999). Elinkeinon edistämisestä koulutuspalvelujen laaduntarkkailuun. Tampereen yliopiston opettajankoulutuslaitos.

Helander, V. (1998). Kolmas sektori: käsitteistöstä, ulottuvuuksista ja tulkinnoista. Gummerus.

Helne, T. (2002). Syrjäytymisen yhteiskunta. Helsingin yliopisto. Sosiaali- ja terveysalan tutkimus- ja kehittämiskeskuksen tutkimuksia123. Gummerus.

Hirvonen, J. \& Martin, M. (1991). Asumisen merkitys hyvinvoinnille. Seurantatutkimus Sirkkulanpuiston asumiskokeilusta. Kuopion yliopisto. Sosiaalitieteiden laitos. Pro gradu -tutkielma.

Hyväri, S. (2001). Vallattomuudesta vastuuseen: kokemuksen politiikan sankaritarinoita. Helsingin yliopisto. Vankeinhoidon koulutuskeskuksen julkaisu 3.

Jahnukainen, M. (1999). Koulutuksellinen syrjäytyminen ja sen ehkäiseminen yläasteen ja toisen asteen nivelvaiheessa. Teoksessa AVO 1998. Ammatinvalinnan ohjauksen vuosikirja. Työministeriö, 75-84.

Japola, H. \& Kuikka, U. (1993). Kyläpiiri yksinäisille asunnottomille. Seurantatutkimus Sirkkulanpuiston asumiskokeilusta. Kuopion yliopisto. Sosiaalitieteiden laitos. Pro gradu -tutkielma.

Jauhiainen, A., Rinne, R. \& Tähtinen, J. (toim. 2001). Koulutuspolitiikka Suomessa ja ylikansalliset mallit. Kasvatusalan tutkimuksia 1. Suomen Kasvatustieteellinen Seura.

Johanson, J-E. (1995). Mielipiteiden luokat ja luokkien mielipiteet. Julkispalveluiden kannatuksen muutos Suomessa 1989-1993. Aikakauskirja Politiikka 2, 99-112.

Jokinen, K. \& Saaristo, K. (2002). Suomalainen yhteiskunta. WSOY.

Laki 493/1999; Asetus 511/1999.

Laurinkari, J. (toim.1994). Oman avun yhteisö erityisryhmien asuntokysymyksen osaratkaisuna. Kuopion Sirkkulanpuisto esimerkkinä 1990-luvun asuntopoliittisesta kehittämishankkeesta. Tutkimusraportti 4. Ympäristöministeriö. Asunto- ja rakennusosasto. 
Laurinkari, J. \& Vilmi, V. (1994). Onko vaihtoehtoisella asuntopolitiikalla tulevaisuutta? Teoksessa J. Laurinkari (toim.) Oman avun yhteisö erityisryhmien asuntokysymyksen osaratkaisuna. Kuopion Sirkkulanpuisto esimerkkinä 1990-luvun asuntopoliittisesta kehittämishankkeesta. Tutkimusraportti 4. Ympäristöministeriö. Asunto- ja rakennusosasto, 36-43.

Lindeneg, K. (1993). Prioritering og styring. København: Akademisk Forlag.

Miettinen, A. (2001). Do co-operatives providing welfare services belong to the third sector? A study of institutional characteristics of Swedish co-operatives. Kuopion yliopisto. Sosiaalitieteiden laitos. Kuopion yliopiston julkaisuja E. Yhteiskuntatieteet 90.

Murphy-Lawless, J. (1991). Sirkkulanpuisto Community, Kuopio. Co-ordinated research programme in the social field (1991/1992). Study Group I on Homelessness. Report on the situation in Finland. Council of Europe.

Mutta-lehti 3/1985.

Nylund, M. (1997). "Oma-apuryhmätkö ratkaisu sosiaalisiin ongelmiin?" Teoksessa J. Simpura \& R. Väärälä (toim.) Yläpolitiikkaa vai alapolitiikkaa? Ehkäisevä sosiaali-ja terveyspolitiikka etsii suuntiaan. Sosiaali- ja terveysministeriön julkaisuja 25, 55-83.

Nylund, M. (2000). Varietes of mutual support and voluntary action. A study of Finnish self-help groups and volunteers. The Finnish Federation for Social Welfare and Health.

O'Cinnéide, S., Abou Sada, G., Clasen, J., KochNielsen, I., Ritakallio, V-M., Kortteinen, M \& Tuomikoski, H. (1995). Social exclusion in Europe. Themes 2. National Research and Development Centre for Welfare and Health.

Piispa, M. \& Kirsi, T. (1986). Raittiustyön muodot ja merkitykset. Tutkimus lehdistön raittiuskirjoittelusta. Tampereen yliopisto. Yhteiskuntatieteiden tutkimuslaitos.

Valtioneuvoston päätös 512/1999.

Vilmi, V. (1993). Kuopiolaisten tyytyväisyys kaupunkiinsa ja sen palveluihin vuonna 1985. Kuopion yliopisto. Sosiaalitieteiden laitos. Kuopion yliopiston julkaisuja E. Yhteiskuntatieteet 13. Väitöskirja.

Vilmi, V. (1996). Die Selbsthilfegesellschaft als wohnungspolitische Lösung. Teoksessa J.
Brazda \& J. Kleer (toim.). Genossenschaften vor neuen Herausforderungen. Festschrift für Prof. DDr. Juhani Laurinkari. Augsburg: Maro Verlag, 305-318.

Vilmi, V. (1999a). Ammatillinen koulutus väline sosiaalistumisessa koulutusyhteiskuntaan. Teoksessa E. Korpinen \& L. Puurula (toim.). Tutkimisen ja löytämisen pasianssia. Professori Jorma Ekolalle omistettu juhlakirja. Tutkiva opettaja 3. Jyväskylä: TUOPE, 67-78.

Vilmi, V. (1999b). Koulutukseen rekrytointi. Kasvatus 30 (4), 359-376.

Vilmi, V. (2003). Koulutus ja koulutukseen valinta. Tutkimus lainsäädäntöön perustuvista hallinnollisista ratkaisuista ja tuloksista. Snellman-instituutin arkistojulkaisu 1. Snellman-instituutti.

Vilmi, V. (2005). Turvallinen koulu. Suomalaisten näkemyksiä koulutuspalvelujen kansallisesta ja kunnallisesta priorisoinnista. University of Jyväskylä. Jyväskylä Studies in Education, Psychology and Social Research 257. Väitöskirja.

\section{Viitteet}

1. Integroitumisen käsitteen tilalle maahanmuuttajien tarkastelussa on otettu käyttöön ns. kotoutumisen käsite (Laki 493/1999; Asetus 511/1999; Valtioneuvoston päätös 512/1999). Yhteiskunta on velvollinen huolehtimaan kotouttamista edistävien toimenpi teiden ja resurssien järjestämisestä, esimerkiksi asumiseen ja koulutuspalveluihin liittyen (vrt. kuvio 3).

2. Artikkelin kirjoittaja on osallistunut tutkijana Laurinkarin (1994) loppuraportin kirjoittamiseen. Raportti on seurantatutkimus, joka sijoittuu ajallisesti lamakauden vuosille 19911993. Se kuvaa oman avun yhteisön welfaremix-periaatteen mukaista toimintaa järjestää aktiivisesti palvelunsa hyvinvointiaan varten. Toimintaan on otettu mukaan yhteisön jäsenten koulutustehtävien suorittamista (ks. myöhemmästä seurannasta, Hakaoja 2003).

3. Tämän artikkelin eräänä lähtökohtana on julkaisuni (Vilmi 1996, 305-318). Se johdattelee yhteiskunnassa viime aikoina pohdintoja aiheuttaneisiin integroitumisen ja sen negaation eli syrjäytymisen käsitteisiin (ks. alaviite 1).

4. Laki maahanmuuttajien kotoutumisesta ja turvapaikanhakijoiden vastaanotosta astui voimaan 1.5.1999. 